\title{
New initiatives for Brazilian aquatic plant data management ${ }^{1}$
}

\section{Marco Otávio Dias Pivari** (1), Pablo Hendrigo Alves de Melo ${ }^{3}$ (1), Filipe Soares Souza ${ }^{4}$ (D), João Renato Stehmann ${ }^{4}$ (D), Edson Gomes de Moura Júnior ${ }^{5}$ (D), Suzana Neves Moreira ${ }^{6}$ (D), Vali Joana Pott ${ }^{7}$ (D, Arnildo Pott ${ }^{7}$ (D), Aline Lopes ${ }^{8}$ (1), Maria Cecilia Chiara Moço ${ }^{9}$ (1) Lukiel dos Santos Oliveira $^{9}$ (1), Alba Lucia de Almeida Lins ${ }^{10}$ (1), Rafael Arruda $^{11}$ (D), Isa Lucia de Morais ${ }^{12}$, Gustavo Santos Silva ${ }^{4}$ (1) and Régis Moreira Ferreira ${ }^{13}$ (1)}

Received: August 8, 2018

Accepted: October 10, 2018

\begin{abstract}
Initiatives directed at managing information on aquatic plants can support different areas of scientific research, educational practices and political decisions for sustainable management and protection of wetlands and natural resources, as well as reveal knowledge gaps regarding aquatic plants and wetlands. Furthermore, such initiatives can contribute directly to consolidating wetland classification systems in Brazil. The objectives of this work are to present and explore the use of a data repository and online platform created specifically for the management of data on aquatic plants in Brazil. The data repository for aquatic plants was developed to store information on species occurrence records in a standardized form considering: systematics, taxonomy, habit, life form, geographic distribution, hydrographic basin, wetland, bibliographic references and herbarium material. A total of 3,903 records referring to the Southeast Region of Brazil were generated for the data repository. This total encompassed 1,036 species distributed among 132 families and 466 genera. Our results illustrate the diversity of information available regarding aquatic plants, circumscribe this group of species and serve as a source of data about them. Similar databases and electronic infrastructures can be developed for other flora in the future.
\end{abstract}

Keywords: aquatic macrophytes, biodiversity conservation, data platform, data repository, environmental variables, wetland classification

\section{Introduction}

Aquatic plants constitute a group of highly diverse and particular organisms with great morphological variation suiting them to different aquatic habitats (Sculthorpe 1985; Lins et al. 2002). The group deserves special attention due to their distinct ecological and economic roles (Esteves 1988; Irgang \& Gastal-Júnior 1996; Pott \& Pott 2000; Rebouças et al. 2006), which make them essential for the

1 Research performed through the Núcleo de Especialistas em Plantas Aquáticas (NEPA) of the Sociedade Botânica do Brasil (SBB) 2 Herbário do Parque Estadual do Rio Doce, Parque Estadual do Rio Doce, Instituto Estadual de Florestas, 35185-000, Marliéria, MG, Brazil 3 Departamento de Botânica, Universidade Estadual Paulista, 13506-900, Rio Claro, SP, Brazil

4 Laboratório de Sistemática Vegetal, Departamento de Botânica, Universidade Federal de Minas Gerais, 30130-000, Belo Horizonte, MG, Brazil 5 Núcleo de Ecologia e Monitoramento Ambiental, Universidade Federal do Vale do São Francisco, 56300-000, Petrolina, PE, Brazil 6 Universidade Estadual de Mato Grosso do Sul, 79400-000, Coxim, MS, Brazil

7 Departamento de Biologia, Universidade Federal de Mato Grosso do Sul, 79070-900, Campo Grande, MS, Brazil 8 Instituto de Ciências Biológicas, Universidade de Brasília, 70910-900, Brasília, DF, Brazil

9 Departamento de Botânica, Universidade Federal do Rio Grande do Sul, 91501-970, Porto Alegre, RS, Brazil 10 Laboratório de Anatomia Vegetal, Museu Paraense Emílio Goeldi, 66040-170, Belém, PA, Brazil

11 Instituto de Ciências Naturais, Humanas e Sociais, Universidade Federal de Mato Grosso, 78550-728, Sinop, MT, Brazil

12 Herbário José Ângelo Rizzo, Universidade Estadual de Goiás, 75860-000, Quirinópolis, GO, Brazil

13 Centro Universitário Belo Horizonte, 30455-610, Belo Horizonte, MG, Brazil

* Corresponding author: marcopivari@yahoo.com.br 
conservation and utilization of water resources, though some can become weeds. Brazil is considered a megadiverse country (Martinelli \& Moraes 2013) with an extensive number of aquatic plant species due to it possessing one of the world's largest and most diversified river networks (Bove et al. 2003). However, comprehensive knowledge regarding wetlands and aquatic plants is needed to counter the lack of protective legislation (NRC 1995; NWWG 1997; Junk et al. 2013).

Research on aquatic plants in Brazil has taken place since the middle of the 1970s, with particularly significant growth after the 1990s (Thomaz \& Bini 2003). To date, publications on aquatic plants have addressed a variety of different subjects but initially included data regarding systematics, taxonomy and ecology (Esteves 1988; Irgang \& Gastal-Júnior 1996; Pedralli 2000; Pott \& Pott 2000). More recent publications have expanded the range of data on species by presenting results of surveys of aquatic plants at regional (Pott \& Pott 2000; Amaral et al. 2008; Bove \& Paz 2009; Pivari et al. 2011; Moura-Júnior et al. 2013; 2015; Bao et al. 2018) and larger scales, such as comparing information from the literature and from Global Biodiversity Information Facility (GBIF) for the South American continent (Lozano et al. 2017). Nevertheless, the knowledge produced over the years regarding aquatic plants in Brazil has not been consolidated in a systematic manner.

Initiatives directed at managing information on biodiversity support the generation of original and comprehensive technical-scientific knowledge in Brazil (FloraRS 2017; Species Link 2017; Flora do Brasil 2020), which can be done for aquatic plants as well, considering their diversity and habitats. Such initiatives with aquatic plants can support different areas of scientific research, educational practices and political decisions for sustainable management and protection of wetlands and natural resources (Pedralli 2000; Junk et al. 2013; Cunha et al. 2015), among other actions. Such initiatives can also reveal knowledge gaps regarding aquatic plants and wetlands and can contribute directly to consolidating wetland classification systems, such as those existing in different countries and undergoing initial development in Brazil (Diegues 1994; NRC 1995; NWWG 1997; Junk et al. 2013; Cunha et al. 2015), by taking into consideration aquatic vegetation as one of the essential parameters for wetland classification.

The objectives of this work are to present and explore the use of a data repository and online platform created specifically for the management of data on aquatic plants in Brazil. We aim to systematize, store and make available information on this component of the Brazilian flora, considering systematics, taxonomy, habit, life form, habitat, wetland type, distribution, hydrographic basin, bibliography, herbarium vouchers and images for the species.

\section{Materials and methods}

\author{
Meaning of the term 'aquatic plants'
}

The term 'aquatic plants' (Hoehne 1955; Cook et al. 1974; Martins \& Carauta 1984; Pott \& Pott 2000; Amaral et al. 2008; Bove \& Paz 2009) was chosen for the title of the present work in order to be less restrictive with regard to the plant species that are attributed to wetlands. Similarly, in the Brazilian bibliographic context, we considered the terms: helophila and limnophila (Warming 1908a; b), aquatic macrophyte (Irgang et al. 1984; Lins et al. 1989; Pedralli 2000), herbaceous aquatic plants (Junk \& Piedade 1993), hydrophyte (Bove et al. 2003) and palustrine plant (Amaral et al. 2008). The choice of these terms is consistent with the most recent scientific publications, whereas the term 'aquatic plants' has been adopted in works of broader character (Pott \& Pott 2000; Amaral et al. 2008). Nonetheless, the term aquatic macrophytes, commonly used in scientific papers in Brazil (Pott et al. 1989; Matias et al. 2003; Ferreira et al. 2010; Pivari et al. 2011), and already internationally recognized (Sculthorpe 1985; Esteves 1988), is becoming more frequently used in limnological reports for typically aquatic species (GastalJúnior et al. 2003).

In this context, species of different plant phyla, such as Carophyta, Bryophyta, Lycopodiopsida, Polypodiopsida and Magnoliophyta (Menezes et al. 2015; PPG I 2016; APG IV 2016), can be considered aquatic plants, reflecting the wide systematic circumscription of this artificial assemblage (Pott \& Pott 2000; Amaral et al. 2008; Ferreira et al. 2011; Pivari et al. 2011; Moura-Júnior et al. 2013; 2015).

\section{Information acquisition}

Herein we present information compiled from scientific publications in the fields of botany and ecology involving regional floras, and floristic, phytosociological and limnological studies, that considered aquatic plants in study areas in Southeast Brazil (Espírito Santo, Minas Gerais, São Paulo and Rio de Janeiro states) up to the middle of the year 2017. The intention was to consolidate the knowledge formally produced and published on this group of organisms.

To survey scientific publications we accessed sites such as Scielo, Periódicos Capes and Google Scholar, plus virtual libraries, and performed searches using the term 'aquatic plants' and the similar terms discussed previously. We also used the names and initials of the states of the Southeast Region of Brazil. Older sources that were not available online were obtained by consulting private libraries, as done by Thomaz \& Bini (2003). We considered complete articles, books, book chapters, doctoral dissertations and master's thesis.

The data repository can be periodically updated through continued searches for new works, thus allowing the addition 
of new information as it appears in the bibliographic context. In addition to information from the scientific literature, the repository will also receive data from herbarium collections or directly from specialists.

\section{Data repository}

The data repository for aquatic plants was developed to store, in a standardized form, information regarding species occurrence records considering: systematics, taxonomy, habit, life form, geographic distribution, hydrographic basin, wetland, bibliographic references and herbarium material (Tabs. S1, S2 in supplementary material).

For the attribute fields for the occurrence records we adopted the terms recommended by the standards of Darwin Core (Darwin Core Terms 2017). The nomenclature and spelling of new attributes, created to control and update the information in the repository, also followed the standards of Darwin Core. The attribute fields were inserted in the data repository to incorporate information from the bibliographic references used as sources of data.

For records with taxonomic identification to the species level we added information from other databases such as, for example, taxonomic group (group), life form (lifeFormFloraBR) and substrate (habitatFloraBR), following Flora do Brasil 2020, and conservation status (threatStatus), according to the Brazilian red list (Lista Vermelha das Espécies da Flora Brasileira Ameaçada de Extinção) (CNCFlora 2017).

The attribute fields for hydrographic basins followed the classification system proposed by Otto Pfafstetter (1989) and adopted in Brazil (CNRH 2002), as follows: Ottobasin levels 1 and 2 corresponding to basins (hydrographicBasin) and sub-basins (hydrographicSubbasin, respectively.

A total of seven data matrices were used (Reference, Author-Reference, Complete-Article, Book, Book-Chapter, Thesis-Dissertation and Specimen-Reference), that compose a relational data bank stored on the MySQL server. Metadata per data matrix and attribute fields are described in Tables S1 and S2 in supplementary material. The data repository is expandable; that is, new attribute fields or matrices can be added at any time, such as to store information on monitoring the risk of invasive aquatic plants, for example. Archives of images of the species can be associated with the records already inserted in the data repository.

We created a web page with search tools and filters to facilitate data access, to permit consultation and, soon, it will allow information download. The storage structure of the data repository allows the recovery of original and updated information for each occurrence record of an aquatic plant published in Brazil. Links to access further information available at the websites Flora do Brasil 2020, GBIF (2017) and CNCFlora (2017) are provided for all species. The application for the web site of the aquatic plants in Brazil was developed in PHP-HTML and is hosted in the domain of the Instituto de Ciências Biológicas of the
Universidade Federal de Minas Gerais (https://sites.icb. ufmg.br/plantasaquaticasbrasil).

\section{Feeding and curatorship of the data repository}

To feed the data repository we initially included information according to the type of publication: scientific article, book, book chapter, master's thesis and doctoral dissertation. Each publication is codified by the combination of a sequential number (associatedReference), starting from 1 in each geographic region of Brazil (brazilianRegion), for example SE-1, NE-1, N-1. This codification is utilized as a key to relate, for example, authors and occurrence records to their respective scientific publication.

Each record in the table Specimen-Reference of the data repository corresponds to one occurrence record of an aquatic plant per publication/ year of record/ locality/ type of habitat/ life form/ habit. Thereby, a species can have more than one record when two or more attributes are mentioned in the same publication. Attribute fields not mentioned in a publication are not considered when filling the fields. The scientific names of families, genera and species, including authors and qualification of identification, were faithfully transcribed from publications for the attributes: family, genus, conferatur (cf.) or affinis (aff.), specific epithet, infraspecific epithet and author name (referenceFamily, referenceGenus, IdentificationQualifier, referenceSpecificEpithet, referenceInfraspecificEpithet, referenceScientificnameauthor, respectively). Scientific names were updated with valid names for families and species according to Flora do Brasil 2020 by means of electronic tools developed in language $\mathrm{R}$ (R Core Team 2014), such as https:// github.com/pablopains/CheckNamesBrazilianFlora2020 and package 'flora', and subsequently validated manually. In this context, the taxonomic classification systems adopted in this work were those proposed by Menezes et al. (2015), PPG I (2016) and APG IV (2016).

Wetland names were faithfully transcribed from publications as an attribute (wetlandReference). Next, the terms attributed to the corresponding wetlands were categorized for subsequent wetland classification following the system proposed by Junk et al. (2013) for Brazil. This system classifies according to the distinction between three central systems, coastal, inland and artificial (Scott \& Jones 1995), followed by subsystems, orders, suborders, classes, subclasses and macrohabitats. Each category of wetland was classified in this sequence, when possible, down to the levels of subclass and macrohabitat (Junk et al. 2013). In the end, we standardized the classification of wetlands encompassed in the publications (classifiedWetland), by indicating the cases of wetlands mapped in the classification system according to the authors or associated by us for the first time to a particular classification (wetlandClassification).

The aquatic plant life forms (lifeForm) considered were amphibious, emergent, epiphytic, rooted floating, free- 
floating, rooted submerged, free submerged (Irgang et al. 1984; Pedralli 1990; Pott \& Pott 2000) and on a floating meadow (embalsado) (Pivari et al. 2011; 2013). The adopted habits (growthForm) were shrub, subshrub, tree, treelet, herb and liana, with liana including scandent and twine (Fidalgo \& Bononi 1984).

We attributed the geographical coordinates and altitude (decimalLatitude, decimalLongitude, altitude) of the study areas reported in the publications for standardization of the geographical distribution per hydrographic basin (hydrographicBasin) and sub-basin (hydrograficSubbasin).

Information regarding registration numbers for vouchers in herbaria and/or collector and collection numbers was only recorded when available in the consulted scientific publication. These were attributed as herbarium (collectionCode) and the number of registration in that collection (catalogNumber), collector (recordedBy) and collector number (recordNumber). Herbarium vouchers were not considered when listed in taxonomic reviews as material examined for descriptions, including examined material and additional examined material.
As previously mentioned, the repository must be fed information made available by newly consulted scientific publications and by herbarium data, or by the manual insertion by specialists. Synonymies must also be periodically updated to follow the dynamic process of the construction of the Flora do Brasil 2020.

\section{Results}

A total of 21 studies on aquatic plants related to Southeast Brazil were considered, including 14 scientific articles, two books, two book chapters, two master's thesis and one doctoral dissertation. A total of 59 researchers, among authors and coauthors, were responsible for the publications (Tab. 1). A total of 3,903 records referring to the Southeast Region were generated in the data repository. The number of records per species was determined by the information contained in the scientific publications, and related to how many times the species was cited in a publication and to the number of attributes mentioned for the species in each bibliographic source.

Table 1. Scientific publications on aquatic plants in Southeast Brazil up to the year 2014.

\begin{tabular}{|c|c|c|c|}
\hline Date & Publication & Title & Author(s) \\
\hline 1908 & Chapter & A formação limnophila Lagoa Santa. & Warming \\
\hline 1908 & Chapter & A vegetação dos brejos e das margens da Lagoa Santa. & Warming \\
\hline 1989 & Article & Plantas palustres e aquáticas que se comportam como invasoras, no Estado de Minas Gerais. & Brandão et al. \\
\hline 1993 & Article & $\begin{array}{l}\text { Levantamento de macrófitos aquáticos e da mata ciliar do reservatório de Volta Grande, Minas } \\
\text { Gerais, Brasil. }\end{array}$ & Pedralli et al. \\
\hline 1996 & Article & $\begin{array}{c}\text { Levantamento da vegetação aquática ("macrófitas) e das florestas de galeria na área da Usina } \\
\text { Hidrelétrica de Nova Ponte, Minas Gerais. }\end{array}$ & Pedralli \& Meyer \\
\hline 1997 & Article & $\begin{array}{c}\text { Levantamento florístico e aspectos da sucessão em duas lagoas na região cárstica de Minas } \\
\text { Gerais, Brasil. }\end{array}$ & Pedralli \& Gonçalves \\
\hline 2003 & Article & $\begin{array}{l}\text { Hidrófitas fanerogâmicas de ecossistemas aquáticos temporários da planície costeira do Estado } \\
\text { do Rio de Janeiro, Brasil. }\end{array}$ & Bove et al. \\
\hline 2003 & Article & $\begin{array}{c}\text { Plantas aquáticas e nível de infestação das espécies presentes no reservatório de Barra Bonita, } \\
\text { no Rio Tietê. }\end{array}$ & Carvalho et al. \\
\hline 2003 & Dissertation & $\begin{array}{c}\text { A comunidade de macrófitas aquáticas em reservatórios do médio e baixo rio Tietê (SP) e em } \\
\text { lagos da bacia do médio rio Doce (MG). }\end{array}$ & Tavares \\
\hline 2007 & Article & Eleocharis R.Br. (Cyperaceae) no Estado do Rio de Janeiro, Brasil. & Gil \& Bove \\
\hline 2007 & Thesis & $\begin{array}{l}\text { Caracterização limnológica e inventário de diversidade das comunidades de macrófitas em cinco } \\
\text { lagoas tropicais: composição florística, biomassa e macroinvertebrados associados. }\end{array}$ & Tavares \\
\hline 2008 & Article & Macrófitas aquáticas da Lagoa Silvana, Vale do Rio Doce, Minas Gerais, Brasil. & Pivari et al. \\
\hline 2008 & Book & Guia de campo para plantas aquáticas e palustres do Estado de São Paulo. & Amaral et al. \\
\hline 2009 & Article & Vegetação vascular litorânea da Lagoa de Jacarepiá, Saquarema, Rio de Janeiro, Brasil. & Barros \\
\hline 2009 & Book & Guia de campo das plantas aquáticas do Parque Nacional da Restinga de Jurubatiba. & Bove \& Paz \\
\hline 2010 & Article & $\begin{array}{c}\text { Estrutura da comunidade de macrófitas aquáticas em três lagoas do Parque Estadual do Rio } \\
\text { Doce, Minas Gerais, Brasil. }\end{array}$ & Ferreira et al. \\
\hline 2010 & Article & $\begin{array}{l}\text { Estudo florístico de plantas vasculares associadas às áreas úmidas na Cadeia do Espinhaço (MG), } \\
\text { Brasil. }\end{array}$ & Meyer \& Franceschinelli \\
\hline 2011 & Article & $\begin{array}{c}\text { Levantamento florístico de um brejo-herbáceo localizado na restinga de Morada do Sol, } \\
\text { município de Vila Velha, Espírito Santo, Brasil. }\end{array}$ & Valadares et al. \\
\hline 2011 & Article & Macrófitas aquáticas do sistema lacustre do Vale do Rio Doce, Minas Gerais, Brasil. & Pivari et al. \\
\hline 2011 & Dissertation & $\begin{array}{l}\text { Levantamento florístico e distribuição de macrófitas aquáticas na Represa Guarapiranga, São } \\
\text { Paulo, Brasil. }\end{array}$ & Rodrigues \\
\hline 2013 & Article & The aquatic macrophyte flora of the Pandeiros River Wildlife Sanctuary, Minas Gerais, Brazil. & Pivari et al. \\
\hline
\end{tabular}


In total, the records encompassed 1,036 species (correct names) distributed among 132 families and 466 genera. Updates of synonymies or spelling corrections were made for less than $30 \%$ (352) of the scientific names recorded in the consulted sources. Circa $12 \%$ (154) of the scientific names were not cited in the Lista de Espécies da Flora do Brasil (Flora do Brasil 2020) and thus were considered unverified names. The citations of Nymphaea ampla (this species does not occur in Brazil) were considered as $N$. pulchella, according to Wiersema et al. (2008).

The ten richest families concentrated more than $50 \%$ of the species: Cyperaceae (116 species), Poaceae (91), Asteraceae (80), Fabaceae (66), Melastomataceae (50), Rubiaceae (36), Onagraceae (29), Lentibulariaceae (24), Orchidaceae (23) and Lamiaceae (22). The genera with more than ten species each were Cyperus (32), Ludwigia (29), Eleocharis (23), Rhynchospora (22), Utricularia (20), Paspalum (17), Cuphea (14), Aeschynomene and Nymphaea (12 each), and Habenaria, Hyptis and Xyris (11 each).

Thirty species with more than 15 records each combined for over $20 \%$ of the records: Polygonum ferrugineum (42), Ludwigia octovalvis (34), L. leptocarpa and Rhynchospora corymbosa (30 each), Cyperus odoratus, Polygonum punctatum (29 each), Cyperus haspan (28), Polygonum hydropiperoides (27), Eichhornia azurea and Eleocharis sellowiana (26 each), E. minima and Utricularia gibba (24 each), Eleocharis interstincta and Typha domingensis (23 each), Juncus microcephalus and Polygonum acuminatum (22 each), Mayaca fluviatilis and Nymphaea pulchella (21 each), Eclipta prostrata, Myriophyllum aquaticum and Salvinia auriculata (20 each), Eleocharis geniculata and Pycreus lanceolatus (19 each), Echinochloa crusgalli, Eichhornia crassipes and Sauvagesia erecta (18 each), Cyperus surinamensis and Heteranthera reniformis (17 each), and Cyperus luzulae and Pistia stratiotes (16 each).

A total of 2,293 records were generated for life forms, pertaining to 790 species. The most frequent life forms were amphibious (1,252 records, 604 species), emergent (829 records, 318 species), rooted floating (129 records, 31 species), on floating meadow (embalsada) (112 records, 92 species), free-floating (111 records, 21 species), rooted submerged (102 records, 34 species), epiphytic (62 records, 46 species) and free submerged (33 records, 10 species). The species with the highest numbers of records related to life forms were Polygonum ferrugineum (40), Ludwigia octovalvis (33), Polygonum punctatum (28), Ludwigia leptocarpa (25), Myriophyllum aquaticum (22), and Cyperus haspan, C. odoratus, Salvinia auriculata and Typha domingensis (two each).

A total of 1,616 records were related to habits of 743 species of aquatic plants. The distribution of the data revealed a greater number of records for herbs $(1,422$ records, 592 species), followed by shrubs (186 records, 104 species), subshrubs (104 records, 65 species), trees (35 records, 28 species) and lianas (32 records, 27 species).
The species with the highest numbers of records related to habit were Polygonum ferrugineum (25), Ludwigia octovalvis (23), Polygonum punctatum (22), Eleocharis sellowiana (18), Juncus microcephalus (16), Ludwigia leptocarpa (14), Boehmeria cylindrica (13), Eleocharis flavescens and Polygonum hydropiperoides (12 each).

Regarding the geographic distribution of species per state, the records in the consulted publications revealed 2,087 records for 693 species of Minas Gerais, 1,151 records and 437 species for São Paulo, 540 records and 262 species for Rio de Janeiro, and 125 records and 111 species for Espírito Santo. Among sampling sites, Represa Guarapiranga (SP) stood out with 443 records, followed by Sistema Lacustre do Vale do Rio Doce (MG) with 358, and Parque Nacional da Restinga de Jurubatiba with 155. Information on aquatic and palustrine plants for São Paulo (Amaral et al. 2008) added 458 records to the data repository.

The 21 scientific works provided information on aquatic plants for three of the five hydrographic basins: Ottobasin level 1 - existing in the Southeast: Rio Paraná, Rio São Francisco and East Atlantic (ANA 2017). Nine of the 21 existing sub-basins (Ottobasin level 2) were sampled in the study areas located within their limits, highlighted by the Rio Doce sub-basin in the East Atlantic basin with 23 study areas, the Rio das Velhas sub-basin in the basin of the Rio São Francisco with nine study areas, plus the sub-basins of Rio Tietê and Litorânea do Rio de Janeiro in the basins of Rio Paraná and East Atlantic, respectively, each with eight study areas. Altogether, 57 study areas were referenced among scientific publications on aquatic plants (Fig. 1).

Wetland information of the Southeast Region extracted from the bibliography totaled 3,015 records for the data repository. Altogether, thirteen categories of wetlands were defined from 36 types cited, and involved all three established systems (Scott \& Jones 1995; Junk et al. 2013): coastal (159 records), inland $(2,177)$ and artificial wetlands (679). Coastal and artificial wetlands, without exception, could be classified to the lower hierarchical levels proposed by Junk et al. (2013), with the final category being macrohabitats. On the other hand, there was some difficulty establishing subclasses/macrohabitats for the 804 records related to inland wetlands (36.9\%), which were finally distributed among five different categories named for the lowest classification level of their respective authors. All this information is shown in Table 2.

The consulted scientific publications produced 1,601 records ( 528 species) possessing information in 16 herbaria. Among these records, 644 are computerized vouchers involving 254 species. Other records of species of aquatic plants for Southeast Brazil were found in other herbaria (INCT 2017; Species Link 2017); however, since in most cases these records represent unpublished data they were not included. 


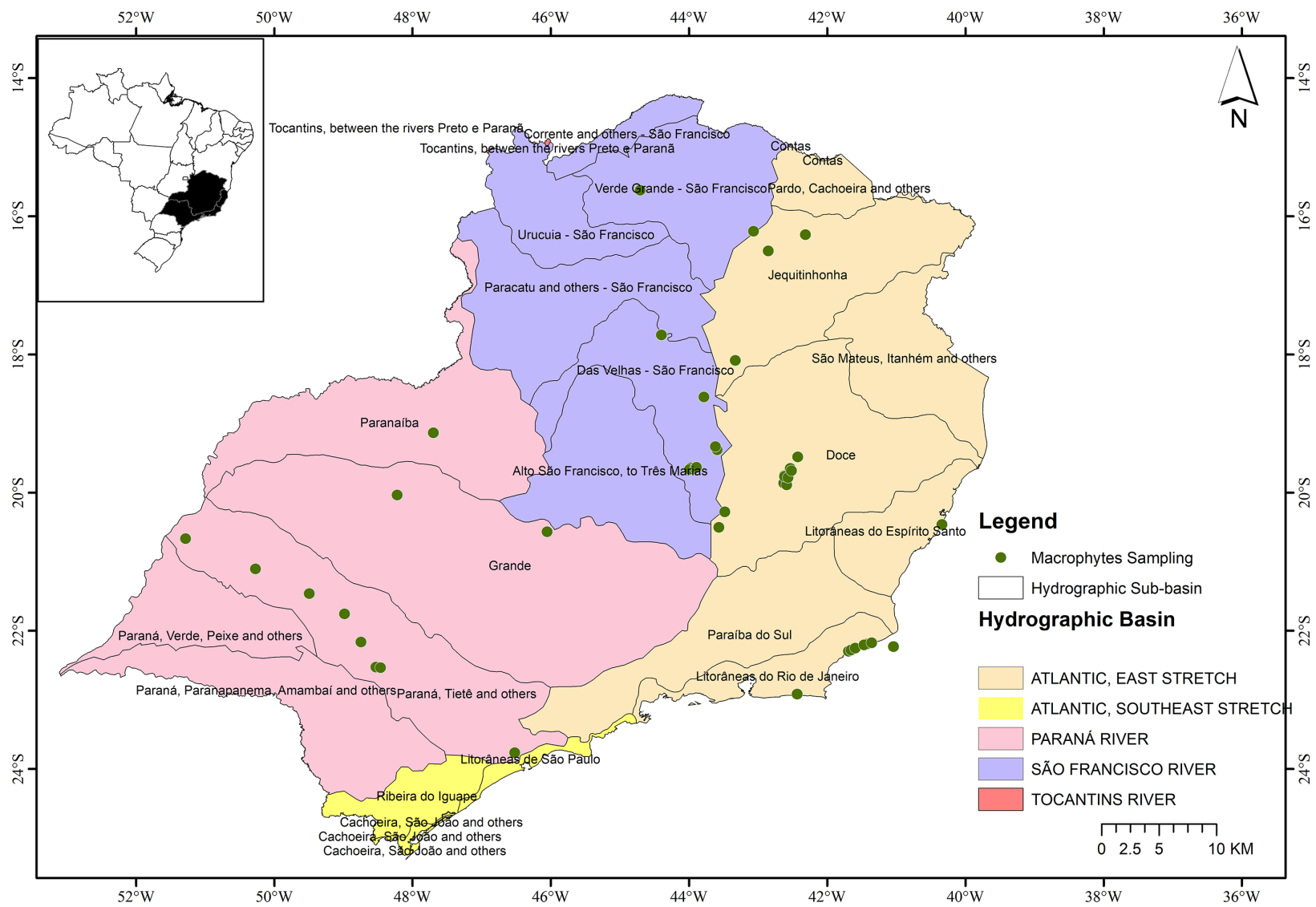

Figure 1. Location of the study areas mentioned in scientific publications on aquatic plants in Southeast Brazil, detailed by hydrographic basins and sub-basins - Ottobasin levels 1 and 2 (ANA 2017).

Table 2. Classification of wetlands cited in scientific works done in Southeast Brazil up to the year 2014, according to the wetland classification system of Junk et al. (2013) and this work. Legend: ReferenceWetland - name of the wetland cited in the scientific publication; System, Subclass, Macrohabitat - hierarchical levels according to Junk et al. (2013); Wetland Classification - final classification of the wetland; N - number of wetlands; Origin - origin of the final classification of the wetland.

\begin{tabular}{|c|c|c|c|c|c|c|}
\hline Reference Wetland & System & Subclass & Macrohabitat & Wetland Classification & N & Oringin \\
\hline $\begin{array}{l}\text { salt herbaceous } \\
\text { marsh }\end{array}$ & $\begin{array}{c}\text { Coastal } \\
\text { wetlands }\end{array}$ & Saltwater wetlands & Salt marshes & Salt marshes & 4 & Junk et al. (2013) \\
\hline $\begin{array}{l}\text { permanent coastal } \\
\text { lake }\end{array}$ & $\begin{array}{c}\text { Coastal } \\
\text { wetlands }\end{array}$ & $\begin{array}{l}\text { Coastal wetlands without } \\
\text { permanent connection to the sea }\end{array}$ & Freshwater lagoons & Freshwater lagoons & 119 & Junk et al. (2013) \\
\hline $\begin{array}{l}\text { temporary coastal } \\
\text { lake }\end{array}$ & $\begin{array}{c}\text { Coastal } \\
\text { wetlands }\end{array}$ & $\begin{array}{l}\text { Coastal wetlands without } \\
\text { permanent connection to the sea }\end{array}$ & $\begin{array}{l}\text { Temporary lakes and } \\
\text { ponds }\end{array}$ & $\begin{array}{l}\text { Temporary lakes and } \\
\text { ponds }\end{array}$ & 36 & Junk et al. (2013) \\
\hline flooded area & $\begin{array}{l}\text { Inland } \\
\text { wetlands }\end{array}$ & $\begin{array}{l}\text { Swamps with multi-species } \\
\text { herbaceous vegetation }\end{array}$ & - & Swamp & 6 & present study \\
\hline swamp & $\begin{array}{l}\text { Inland } \\
\text { wetlands }\end{array}$ & $\begin{array}{l}\text { Swamps with multi-species } \\
\text { herbaceous vegetation }\end{array}$ & - & Swamp & 3 & present study \\
\hline herbaceous swamp & $\begin{array}{l}\text { Inland } \\
\text { wetlands }\end{array}$ & $\begin{array}{l}\text { Swamps with multi-species } \\
\text { herbaceous vegetation }\end{array}$ & - & Swamp & 338 & present study \\
\hline swamp & $\begin{array}{l}\text { Inland } \\
\text { wetlands }\end{array}$ & $\begin{array}{l}\text { Swamps with multi-species } \\
\text { herbaceous vegetation }\end{array}$ & - & Swamp & 84 & present study \\
\hline palustrine & $\begin{array}{l}\text { Inland } \\
\text { wetlands }\end{array}$ & $\begin{array}{l}\text { Swamps with multi-species } \\
\text { herbaceous vegetation }\end{array}$ & - & Swamp & 599 & present study \\
\hline swamp & $\begin{array}{l}\text { Inland } \\
\text { wetlands }\end{array}$ & $\begin{array}{l}\text { Swamps with multi-species } \\
\text { herbaceous vegetation }\end{array}$ & - & Swamp & 2 & present study \\
\hline $\begin{array}{l}\text { flood prone } \\
\text { grassland }\end{array}$ & $\begin{array}{l}\text { Inland } \\
\text { wetlands }\end{array}$ & - & - & $\begin{array}{l}\text { Other hydromorphic } \\
\text { climatic savannas }\end{array}$ & 2 & Junk et al. (2013) \\
\hline
\end{tabular}


Table 2. Cont.

\begin{tabular}{|c|c|c|c|c|c|c|}
\hline Reference Wetland & System & Subclass & Macrohabitat & Wetland Classification & N & Oringin \\
\hline altitude grassland & $\begin{array}{l}\text { Inland } \\
\text { wetlands }\end{array}$ & - & - & $\begin{array}{l}\text { Other hydromorphic } \\
\text { climatic savannas }\end{array}$ & 1 & Junk et al. (2013) \\
\hline wet open grassland & $\begin{array}{l}\text { Inland } \\
\text { wetlands }\end{array}$ & - & - & $\begin{array}{l}\text { Other hydromorphic } \\
\text { climatic savannas }\end{array}$ & 1 & Junk et al. (2013) \\
\hline floodable grassland & $\begin{array}{l}\text { Inland } \\
\text { wetlands }\end{array}$ & - & - & $\begin{array}{l}\text { Other hydromorphic } \\
\text { climatic savannas }\end{array}$ & 42 & Junk et al. (2013) \\
\hline puddle & $\begin{array}{c}\text { Inland } \\
\text { wetlands }\end{array}$ & - & $\begin{array}{l}\text { Rain water fed wetlands in } \\
\text { small depressions }\end{array}$ & $\begin{array}{l}\text { Rain water fed wetlands } \\
\text { in small depressions }\end{array}$ & 1 & Junk et al. (2013) \\
\hline waterlogged soil & $\begin{array}{l}\text { Inland } \\
\text { wetlands }\end{array}$ & - & $\begin{array}{l}\text { Rain water fed wetlands in } \\
\text { small depressions }\end{array}$ & $\begin{array}{l}\text { Rain water fed wetlands } \\
\text { in small depressions }\end{array}$ & 2 & Junk et al. (2013) \\
\hline wet soil & $\begin{array}{l}\text { Inland } \\
\text { wetlands }\end{array}$ & - & $\begin{array}{l}\text { Rain water fed wetlands in } \\
\text { small depressions }\end{array}$ & $\begin{array}{l}\text { Rain water fed wetlands } \\
\text { in small depressions }\end{array}$ & 8 & Junk et al. (2013) \\
\hline waterfall & $\begin{array}{l}\text { Inland } \\
\text { wetlands }\end{array}$ & - & - & River & 5 & present study \\
\hline river rock & $\begin{array}{l}\text { Inland } \\
\text { wetlands }\end{array}$ & - & - & River & 1 & present study \\
\hline permanente creek & $\begin{array}{l}\text { Inland } \\
\text { wetlands }\end{array}$ & - & - & River & 4 & present study \\
\hline water course & $\begin{array}{l}\text { Inland } \\
\text { wetlands }\end{array}$ & - & - & River & 1 & present study \\
\hline river margin & $\begin{array}{c}\text { Inland } \\
\text { wetlands }\end{array}$ & - & - & River & 4 & present study \\
\hline permanent river & $\begin{array}{c}\text { Inland } \\
\text { wetlands }\end{array}$ & - & - & River & 119 & present study \\
\hline forest edge & $\begin{array}{l}\text { Inland } \\
\text { wetlands }\end{array}$ & - & $\begin{array}{l}\text { Riparian wetlands along } \\
\text { small rivers (1-5th order) }\end{array}$ & $\begin{array}{l}\text { Riparian wetlands } \\
\text { along small rivers }\end{array}$ & 1 & Junk et al. (2013) \\
\hline riparian forest & $\begin{array}{l}\text { Inland } \\
\text { wetlands }\end{array}$ & - & $\begin{array}{l}\text { Riparian wetlands along } \\
\text { small rivers (1-5th order) }\end{array}$ & $\begin{array}{l}\text { Riparian wetlands } \\
\text { along small rivers }\end{array}$ & 34 & Junk et al. (2013) \\
\hline gallery forest & $\begin{array}{l}\text { Inland } \\
\text { wetlands }\end{array}$ & - & $\begin{array}{l}\text { Riparian wetlands along } \\
\text { small rivers (1-5th order) }\end{array}$ & $\begin{array}{l}\text { Riparian wetlands } \\
\text { along small rivers }\end{array}$ & 1 & Junk et al. (2013) \\
\hline marginal lake & $\begin{array}{l}\text { Inland } \\
\text { wetlands }\end{array}$ & - & $\begin{array}{l}\text { Riparian wetlands along } \\
\text { small rivers (1-5th order) }\end{array}$ & $\begin{array}{l}\text { Riparian wetlands } \\
\text { along small rivers }\end{array}$ & 244 & Junk et al. (2013) \\
\hline oxbow lake & $\begin{array}{l}\text { Inland } \\
\text { wetlands }\end{array}$ & - & $\begin{array}{l}\text { Riparian wetlands along } \\
\text { small rivers (1-5th order) }\end{array}$ & $\begin{array}{l}\text { Riparian wetlands } \\
\text { along small rivers }\end{array}$ & 50 & Junk et al. (2013) \\
\hline forest inside & $\begin{array}{l}\text { Inland } \\
\text { wetlands }\end{array}$ & - & - & Flooding forests & 1 & Junk et al. (2013) \\
\hline altitude forest & $\begin{array}{l}\text { Inland } \\
\text { wetlands }\end{array}$ & - & - & Flooding forests & 1 & Junk et al. (2013) \\
\hline lagoon & $\begin{array}{l}\text { Inland } \\
\text { wetlands }\end{array}$ & - & - & Lake & 1 & present study \\
\hline permanent lake & $\begin{array}{l}\text { Inland } \\
\text { wetlands }\end{array}$ & - & - & Lake & 608 & present study \\
\hline lake shore & $\begin{array}{l}\text { Inland } \\
\text { wetlands }\end{array}$ & - & - & Lake & 1 & present study \\
\hline temporary pond & $\begin{array}{c}\text { Inland } \\
\text { wetlands }\end{array}$ & - & - & Temporary lake & 12 & Junk et al. (2013) \\
\hline impoundment & $\begin{array}{l}\text { Artificial } \\
\text { wetlands }\end{array}$ & - & Water reservoirs & $\begin{array}{l}\text { Artificial water } \\
\text { reservoirs }\end{array}$ & 56 & Junk et al. (2013) \\
\hline dam & $\begin{array}{l}\text { Artificial } \\
\text { wetlands }\end{array}$ & - & Water reservoirs & $\begin{array}{l}\text { Artificial water } \\
\text { reservoirs }\end{array}$ & 508 & Junk et al. (2013) \\
\hline reservoir & $\begin{array}{l}\text { Artificial } \\
\text { wetlands }\end{array}$ & - & Water reservoirs & $\begin{array}{l}\text { Artificial water } \\
\text { reservoirs }\end{array}$ & 109 & Junk et al. (2013) \\
\hline channel & $\begin{array}{l}\text { Artificial } \\
\text { wetlands }\end{array}$ & - & Drainage channels & $\begin{array}{l}\text { Artificial drainage } \\
\text { channels }\end{array}$ & 6 & Junk et al. (2013) \\
\hline
\end{tabular}




\section{Discussion}

Scientific publications on aquatic plants were recovered for all the states of the Southeast Region of Brazil, with 13 for Minas Gerais, five for São Paulo, four for Rio de Janeiro and one for Espírito Santo. The field guide Guia de Campo das Plantas Aquáticas e Palustres do Estado de São Paulo (Amaral et al. 2008) stands out from the other works done in the region due to its geographic breadth. However, given the extent of the Southeast, the representation of the scientific production on aquatic plants can yet be considered incipient, except for the lacustrine system of Vale do Rio Doce (Tavares 2003; 2007; Pivari et al. 2008; 2011; Ferreira et al. 2010), and localized, indicating knowledge gaps given the presence of relevant wetlands in the region, including Ramsar Sites (MMA 2017).

An important landmark in the development of botanical and ecological knowledge in Brazil, Lagoa Santa: Contribuição para geographia phytobiologica, includes two chapters on aquatic vegetation (Warming 1908a; b), which were considered in the present work. Subsequent compiled works were published only at the end of the 1980s and early 1990s, corroborating the distribution recognized by Thomaz \& Bini (2003) that the largest volume of reports on aquatic plants in the Southeast appeared after 2000 (Tab. 1).

It is worth noting that other scientific reports published prior to 2014 that were not surveyed in searches for this work, and new publications thereafter, will have their information incorporated into the data repository. Likewise, other regions of Brazil will be considered for aquatic plant data management following the methods proposed herein (e.g., Oliveira 2016), in order to encompass, in an integrated manner, the scientific knowledge produced in Brazil such that it can direct future research efforts with aquatic plants and wetlands.

The sampling of the Southeast Region revealed a very diverse group of species and that its established circumscription, considering different authors (Tab. 1), has broad systematic coverage. Based on 21 publications, over a thousand species were recorded distributed among more than 130 families and 460 genera, including representatives of Algae, Bryophyta, Pteridophyta, Lycophyta and Angiospermae. Therefore, the range of plant species considered and classified as aquatic encompasses individual occurrence records in wetlands, without interest in establishing a natural group (Judd et al. 2009).

Aside from designating the group of species considered aquatic macrophytes, the obtained systematic and taxonomical information, as well as that related to species habit, directly support wetland classification by botanical parameters that have already been adopted (Maltchik et al. 2004; Junk et al. 2013; Cunha et al. 2015). Likewise, the data obtained on life forms also possess great potential as a parameter for the classification of wetlands. Life forms show the physical structuring of aquatic niches in wetlands, and thus represent an important descriptive character. Nonetheless, life forms have been little applied in this manner. With regard to plant habit, representatives of all the considered habits were observed.

The set of obtained data contributed to the inventory of wetlands in Brazil, which remains in its infancy (Junk et al. 2013). It also contributed to the classification of wetlands of the Southeast by including regional terms present in the literature and related to inland wetlands, which advances the systematization of the terminology used in their classification (Cunha et al. 2015). This work also contributes by making available information associating aquatic plant species with Brazilian wetlands, and consolidating, in a systematized way, knowledge of aquatic plants as it relates to the classification of wetlands (Junk et al. 2013; Cunha et al. 2015), for research and for their sustainable management and protection (Junk et al. 2013).

The geographic coordinates of the study areas of the consulted works were attributed to the cited species, thus this research helps to generate proper geographic distributions based on the records of aquatic plants in scientific publications up to the present. At the same time, the distribution of species in relation to hydrographic basins, referred to as hydrographic distribution in Flora do Brasil 2020, revealed an area of knowledge regarding the set of species considered in this work that is not yet clear. Such information is important for understanding the geographic and hydrographic distributions (Flora do Brasil 2020) of aquatic plants in wetlands of Brazil.

As of yet it has not been possible to make a thorough assessment about the set of data present in herbaria regarding aquatic plants because there has yet to be a comprehensive work for this group in a national context. Furthermore, collection records do not always indicate that a particular specimen in a herbarium corresponds to a species classified as an aquatic plant. Therefore, individualized interpretations of these records in relation to specimens and collection areas is necessary to determine, for example, if they actually correspond to wetlands or not. In this context, the database presented herein serves to increase the information available on aquatic plants from herbaria, which will allow a better understanding of the range of taxa considered to be aquatic plants and of their occurrence in Brazilian wetlands.

Our results illustrate the diversity of information available regarding aquatic plants present in scientific publications, circumscribes this group of species and serves as a source of data about them. Similar databases and electronic infrastructures of this type (GBIF 2017; SiBBr 2017; Species Link 2017; Flora do Brasil 2020) can be developed for other floras in the future (Canhos et al. 2015; Costello 2015), resulting in efforts to integrate knowledge of plant diversity in a Brazilian context (Silva et al. 2017). In addition to the analyses presented herein, 
which can serve as a model for future publications of similar nature for other regions, or even for the Southeast, the data repository will evolve and begin to support research on other themes. The addition of other information about taxa and their associated wetlands, such as seasonality, flow, turbidity, temperature, $\mathrm{pH}$, conductivity, and nutrient concentrations in the water and substrate, can support future works involving limnology, predictive modeling, potential distribution of species, cultivation and monitoring and management of aquatic macrophytes in reservoirs, among others.

The database presented herein represents the original release of scientific information about aquatic plants in a systematized form and covering a variety of their features, which is important and expected to be widely used. Access to these data promotes scientific development in general, and improvements to the quality of technical-scientific work in the academic fields, environmental consulting, teaching and environmental education, as well as provisioning reliable information to society, among other possibilities. In all cases, the promotion of knowledge in this area contributes to political decision making, with the aim of benefiting biodiversity and wetland conservation.

\section{Acknowledgements}

The authors thank the Sociedade Botânica do Brasil for the support provided to the Núcleo de Especialistas em Plantas Aquáticas. We also thank CAPES for providing a research scholarship to A. Lopes and A. Pott, PROBIP/ UEG for providing a research scholarship to I. L. Morais and FAPESP for a fellowship grant 2015/13112-7 to P. H. A. Melo. To Erik Wild for English revision.

\section{References}

Amaral MCE, Bittrich V, Faria AD, Anderson LO, Aona LYS. 2008. Guia de campo para plantas aquáticas e palustres do Estado de São Paulo. Ribeirão Preto, Holos Editora.

ANA - Agência Nacional das Águas. 2017. Divisão hidrográfica. http:// metadados.ana.gov.br/geonetwork/srv/pt/main.home

APG IV - The Angiosperm Phylogeny Group. 2016. An update of the Angiosperm Phylogeny Group classification for the orders and families of flowering plants: APG IV. Botanical Journal of the Linnean Society 181: 1-20.

Bao F, Leandro TD, Rocha M, et al. 2018. Plant species diversity in a Neotropical wetland: patterns of similarity, effects of distance, and altitude. Anais da Academia Brasileira de Ciências 90: 85-97.

Barros AAM. 2009. Vegetação vascular litorânea da Lagoa de Jacarepiá, Saquarema, Rio de Janeiro, Brasil. Rodriguésia 60: 97-110.

Bove CP, Gil ASB, Moreira CB, Anjos RFB. 2003. Hidrófitas fanerogâmicas de ecossistemas aquáticos temporários da planície costeira da Estado do Rio de Janeiro, Brasil. Acta Botanica Brasilica 17: 119-135.

Bove CP, Paz J. 2009. Guia de campo das plantas aquáticas do Parque Nacional da Restinga de Jurubatiba. Rio de Janeiro, Editora do Museu Nacional.

Brandão M, Laca-Buendia JP, Gavilanes ML. 1989. Plantas palustres e aquáticas que se comportam como invasoras, no Estado de Minas Gerais. Acta Botanica Brasilica 2: 255-265.
Canhos DAL, Sousa-Baena MS, Souza S, et al. 2015. The importance of biodiversity e-infrastructures for megadiverse countries. PLOS Biology 13: e1002204. doi: 10.1371/journal.pbio.1002204

Carvalho FT, Galo MLBT, Velini ED, Martins D. 2003. Plantas aquáticas e nível de infestação das espécies presentes no reservatório de Barra Bonita, no Rio Tietê. Planta Daninha 21: 15-19.

CNCFlora - Centro Nacional de Conservação da Flora. 2017. Lista vermelha. http://cncflora.jbrj.gov.br

CNRH - Conselho Nacional dos Recursos Hídricos. 2002. Resolução No 30, de 11 de dezembro de 2002. Brasília, Diário Oficial da União.

Cook CDK, Gut BJ, Rix EM, Schneller J, Seitz M. 1974. Water plants of the world: a manual for the identification of the genera of freshwater macrophytes. The Hague, Dr. W. Junk Publishers.

Costello MJ. 2015. Strategies for the sustainability of online open-access biodiversity databases. Biological Conservation 173: 155-165.

Cunha CN, Piedade MTF, Junk WJ. 2015. Classificação e delineamento das áreas úmidas brasileiras e de seus macrohabitats. Cuiabá, UFMT.

Darwin Core Terms. 2017. Darwin Core Terms: A quick reference guide. http://tdwg.github.io/dwc/terms

Diegues ACS. 1994. An inventory of Brazilian wetlands. Gland, IUCN - The World Conservation Union.

Esteves FA. 1988. Fundamentos de limnologia. Rio de Janeiro, Interciência. Ferreira FA, Mormul RP, Pedralli G, Pott VJ, Pott A. 2010. Estrutura da comunidade de macrófitas aquáticas em três lagoas do Parque Estadual do Rio Doce, Minas Gerais, Brasil. Hoehnea 37: 43-52.

Ferreira FA, Mormul RP, Thomaz SM, Pott A, Pott VJ. 2011. Macrophytes in the upper Paraná river floodplain: checklist and comparison with other large South American wetlands. Revista de Biología Tropical 59: 541-556.

Fidalgo O, Bononi VLR. 1984. Técnicas de coleta, preservação e herborização de material botânico. São Paulo, Instituto de Botânica.

Flora do Brasil 2020 em construção. 2017. Flora do Brasil. Rio de Janeiro, Jardim Botânico do Rio de Janeiro. http://floradobrasil.jbrj.gov.br

FloraRS - Flora Digital dos Estados do Rio Grande do Sul e de Santa Catarina. 2017. Acervo. http://www.ufrgs.br/fitoecologia/florars/ index.php?pag=apresenta.php

Gastal-Júnior CVS, Irgang BE, Moreira C. 2003. Problemas com infestação de macrófitas aquáticas na área de influência da usina hidrelétrica de Itá. Acta Scientiae 5: 87-92.

GBIF - Global Biodiversity Information Facility. 2017. Acesso livre e aberto a dados de biodiversidade. https://www.gbif.org

Gil ASB, Bove CP. 2007. Eleocharis R.Br. (Cyperaceae) no Estado do Rio de Janeiro, Brasil. Biota Neotropica 7: 163-193.

Hoehne FC. 1955. Plantas aquáticas. São Paulo, Secretaria de Agricultura de São Paulo.

INCT - Instituto Nacional de Ciência e Tecnologia. 2017. Herbário virtual da flora e dos fungos. http://inct.splink.org.br

Irgang BE, Gastal-Júnior VCS. 1996. Macrófitas aquáticas da planície costeira do RS. Porto Alegre, Edição dos Autores.

Irgang BE, Pedralli G, Waechter JI. 1984. Macrófitos aquáticos da Estação Ecológica do Taim, Rio Grande do Sul, Brasil. Roessleria 6: 395-404.

Judd WS, Campbell CS, Kellogg EA, Stevens PF, Donoghue MJ. 2009. Sistemática vegetal: um enfoque filogenético. Porto Alegre, Artmed.

Junk WJ, Piedade MTF. 1993. Herbaceous plants of the Amazon floodplain near Manaus: Species diversity and adaptations to the flood pulse. Amazoniana 12: 467-484.

Junk WJ, Piedade MTF, Lourival R, et al. 2013. Brazilian wetlands: their definition, delineation, and classification for research, sustainable management, and protection. Aquatic Conservation: Marine and Freshwater Ecosystems 24: 5-22.

Lins ALFA, Vilhena-Potiguara RC, Rosa NA, Ribeiro IC. 1989. Macrófitas aquáticas de uma área de Barcarena, Pará, Brasil. Boletim do Museu Paraense Emílio Goeldi, Série Botânica 5: 135-144.

Lins ALFA, Tostes LCL, Vilhena-Potiguara RC, Lobato LC. 2002. Macrófitas Aquáticas de Caxiuanã. In: Lisboa PL. (org.) Caxiuanã: Pesquisa \& Desenvolvimento Sustentável. Belém, Museu Goeldi. p. 369-377.

Lozano V, Chapman DS, Brundu G. 2017. Native and non-native aquatic plants of South America: comparing and integrating GBIF records with literature data. Management of Biological Invasions 8: 443-454. 
Maltchik L, Rolon AS, Guadagnin DL, Stenert C. 2004. Wetlands of Rio Grande do Sul, Brazil: a classification with emphasis on plant communities. Acta Limnologica Brasiliensia 16: 137-151.

Martinelli G, Moraes MA. 2013. Livro vermelho da flora do Brasil. Rio de Janeiro, Andrea Jakobsson: Instituto de Pesquisas Jardim Botânico do Rio de Janeiro.

Martins HF, Carauta JPP. 1984. Plantas aquáticas. Classificação e comentários. Atas da Sociedade Botânica do Brasil 2: 101-104.

Matias LQ, Amado ER, Nunes EP. 2003. Macrófitas aquáticas da lagoa de Jijoca de Jericoacoara, Ceará, Brasil. Acta Botanica Brasilica 17: 623-631.

Menezes M, Bicudo CEM, Moura CWN, et al. 2015. Update of the Brazilian floristic list of Algae and Cyanobacteria. Rodriguésia 66:1047-1062.

Meyer ST, Franceschinelli EV. 2010. Estudo florístico de plantas vasculares associadas às áreas úmidas na Cadeia do Espinhaço (MG), Brasil. Brazilian Journal of Botany 33: 677-691.

MMA - Ministério do Meio Ambiente. 2017. Sítios Ramsar do Brasil. http://www.mma.gov.br/areas-protegidas/instrumentos-de-gestao/ s\%C3\%ADtios-ramsar

Moura Júnior EG, Lima LF, Silva SSL, et al. 2013. Aquatic macrophytes of Northeastern Brazil: Checklist, richness, distribution and life forms. Check List 9: 298-312.

Moura Júnior EG, Paiva RMS, Ferreira AC, et al. 2015. Updated checklist of aquatic macrophytes from Northern Brazil. Acta Amazônica 45: 111-132.

NRC - National Research Council. 1995. Wetlands: characteristics and boundaries. Washington, National Academy Press.

NWWG - National Wetlands Working Group. 1997. The Canadian wetland classification system. Waterloo, Wetland Research Centre Publication.

Oliveira LS. 2016. Abordagem florística e quantitativa de áreas úmidas no sul do brasil. MSc Thesis, Universidade Federal do Rio Grande do Sul, Porto Alegre.

Pedralli G. 1990. Macrófitos aquáticos: técnicas e métodos de estudos. Estudos de Biologia 26: 5-24.

Pedralli G. 2000. Padrões florísticos como subsídios à conservação da biodiversidade de macrófitas aquáticas. In: Cavalcanti TB, Walter BMT. (orgs.) Tópicos Atuais em Botânica. Brasília, Embrapa. p. 335-339.

Pedralli G, Gonçalves APS. 1997. Levantamento florístico e aspectos da sucessão em duas lagoas da região cárstica de Minas Gerais, Brasil. Daphne 7: 17-25.

Pedralli G, Meyer ST. 1996. Levantamento da vegetação aquática ("macrófitas") e das florestas de galeria na área da Usina Hidrelétrica de Nova Ponte, Minas Gerais. Bios 4: 49-60.

Pedralli G, Meyer ST, Teixeira MC, Stehmann JR. 1993. Levantamento de macrófitos aquáticos e da mata ciliar do reservatório de Volta Grande, Minas Gerais, Brasil. Iheringia, Série Botânica 43: 29-40.

Pfafstetter O. 1989. Classificação de bacias hidrográficas: metodologia da codificação. Rio de Janeiro, Departamento Nacional de Obras de Saneamento (DNOS).

Pivari MOD, Oliveira VB, Costa FM, Ferreira RM, Salino A. 2011. Macrófitas aquáticas do sistema lacustre do Vale do Rio Doce, Minas Gerais, Brasil. Rodriguésia 62: 759-770.

Pivari MOD, Salimena FRG, Pott VJ, Pott A. 2008. Macrófitas aquáticas da lagoa Silvana, Vale do Rio Doce, Minas Gerais, Brasil. Iheringia, Série Botânica 63: 321-327.
Pivari MOD, Viana PL, Leite FSF. 2013. The aquatic macrophyte flora of the Pandeiros River Wildlife Sanctuary, Minas Gerais, Brazil. Check List 9: 415-424.

Pott VJ, Bueno NC, Pereira RAC, Salis SM, Vieira NL. 1989. Distribuição de macrófitas aquáticas numa lagoa na fazenda Nhumirim, Nhecolândia, Pantanal, MS. Acta Botanica Brasilica 3: 153-168

Pott VJ, Pott A. 2000. Plantas Aquáticas do Pantanal. Corumbá, Embrapa. PPG I - The Pteridophyte Phylogeny Group. 2016. A community-derived classification for extant lycophytes and ferns. Journal of Systematics and Evolution 54: 563-603.

R Core Team. 2014. R: A language and environment for statistical computing. Vienna, R Foundation for Statistical Computing. http:// www.R-project.org

Rebouças AC, Braga B, Tundisi JG. 2006. Águas doces no Brasil: Capital ecológico, uso e conservação. São Paulo, Escrituras.

Rodrigues MEF. 2011. Levantamento florístico e distribuição de macrófitas aquáticas na Represa Guarapiranga, São Paulo, Brasil. MSc Thesis, Universidade de São Paulo, São Paulo.

Scott DA, Jones TA. 1995. Classification and inventory of wetlands: a global overview. Vegetatio 118: 3-16.

Sculthorpe CD. 1985. The biology of aquatic vascular plants. London, Edward Arnold Publishers.

SiBBr - Sistema de Informação sobre a Biodiversidade brasileira. 2017. Biodiversidade brasileira. http://www.sibbr.gov.br

Silva LAE, Fraga CN, Almeida TMH, et al. 2017. Jabot - Sistema de gerenciamento de coleções botânicas: a experiência de uma década de desenvolvimento e avanços. Rodriguésia 68: 391-410.

Species Link. 2017. SpeciesLink network. http://www.splink.org.br

Tavares KS. 2003. A comunidade de macrófitas aquáticas em reservatórios do médio e baixo rio Tietê (SP) e em lagos da bacia do médio rio Doce (MG). MSc Thesis, Universidade Federal de São Carlos, São Carlos.

Tavares KS. 2007. Caracterização limnológica e inventário de diversidade das comunidades de macrófitas em cinco lagoas tropicais: composição florística, biomassa e macroinvertebrados associados. PhD Thesis, Universidade Federal de São Carlos, São Carlos.

Thomaz SM, Bini LM. 2003. Análise crítica dos estudos sobre macrófitas aquáticas desenvolvidos no Brasil. In: Thomaz SM, Bini LM. (eds.) Ecologia e manejo de macrófitas aquáticas. Maringá, Editora da Universidade Estadual de Maringá. p. 19-38.

Valadares RT, Souza FBC, Castro NGD, Peres ALSS, Schneider SZ, Martins MLL. 2011. Levantamento florístico de um brejo-herbáceo localizado na restinga de Morada do Sol, município de Vila Velha, Espírito Santo, Brasil. Rodriguésia 62: 827-834.

Warming E. 1908a. A formação limnophila Lagoa Santa. In: Warming E. (ed.) Contribuição para geographia phytobiologica. Belo Horizonte, Imprensa Official. p. 174-177.

Warming E. 1908b. A vegetação dos brejos e das margens da lagoa Lagoa Santa. In: Warming E. (ed.) Contribuição para geographia phytobiologica. Belo Horizonte, Imprensa Official. p. 168-174.

Wiersema JH, Novelo AR, Bonilla-Barbosa JR. 2008. Taxonomy and typification of Nymphaea ampla (Salisb.) DC. sensu lato (Nymphaeaceae). Taxon 57: 967-974. 